\title{
Assured Newcomers on a Squally Sea? The Czech Pirate Party before and after the 2017 Elections
}

\section{Daniel Šárovec*}

Charles University

\begin{abstract}
The elections to the Chamber of Deputies in October 2017 were a turning point for the Czech Pirate Party (called "Piráti"). It was the first time since establishing the party in 2009 that the Pirates entered the lower house of the Czech Parliament. They took the third place with $10.79 \%$ votes and won 22 seats out of 200 . Their main programme points came out of typical "pirate policies" like control of power and the powerful ones, simplification of the running of the state through technology, protection of citizens from bullying and defence of freedom as well as basic Pirate principles including liberalism and direct democracy. Their programme was called "New Ideas for the New Age". From a different view, this party presented itself as a watchdog of democracy and as an alternative mostly for liberal voters. This qualitative case study will provide a complex overview of the Pirate phenomenon in the Czech Republic from their establishment to their current role of an opposition party. This article aims to show and describe how the position of the Czech Pirates has varied over time. For this purpose, open data from the Czech Statistical Office (CZSO) and the findings from the Chapel Hill Expert Survey (CHES) dataset will be used. It is possible to say that the Pirates are playing the role of newcomers in the Chamber of Deputies after the 2017 elections, but they are not newcomers in the Czech party system.
\end{abstract}

\section{Keywords}

Czech party system, Czech Pirate party, democracy, elections, new political parties, newness, pirate parties, Pirates, political parties, PP-CZ

\section{Introduction}

The research into the theoretical and practical aspects of the emergence of new political parties has become an indispensable object of interest to a wide range of researchers since the second half of the $20^{\text {th }}$ century. ${ }^{1}$ It is not surprising, therefore, that other significant studies are currently being dealt with in this respect from different points of view (e.g. Bolleyer, Bytzek 2017; KosowskaGąstoł, Sobolewska-Myślik 2017; Krašovec 2017; Ait-Aoudia 2018; Emanuele, Chiaramonte 2018; Hynčica, Šárovec 2018; Vidal 2018; Malčič, Krašovec 2019 or Stankov 2019), which only highlights the relevance of the topic.

* Corresponding Author: Daniel Šárovec, Department of Political Science, Institute of Political Studies, Faculty of Social Sciences, Charles University, U Krize 8, 15800 Prague, Czech Republic. E-mail: daniel.sarovec@fsv.cuni.cz.

${ }^{1}$ For a broader conceptualisation of this topic, see Š́rovec (2016). 
Among the numerous new parties entering the parliament in European democracies in recent years, some of them (like the German Alternative for Germany (AfD), Italian Five Star Movement (M5S) or Austrian NEOS - The New Austria and Liberal Forum (NEOS)) have demonstrated a level of success which seems to be more than a "one-hit-wonder", whereas others disappeared almost as quickly as they rose (e.g. the Austrian Team Stronach, or some Pirate parties). Central Europe is not an exception to this trend (see Bakke, Sitter 2015; Filipec 2019; Kosowska-Gąstoł, Sobolewska-Myślik 2017 and 2019 or Marušiak 2017). Even the Czech Republic has experienced significant transformations of the party system in recent years connected with the successful breakthrough of newcomers; thus, it has not lagged behind in this respect (see Polášek et al. 2014: 148 or Chavát, Just 2016). The professional literature from Czech authors focusing on Czech parties ${ }^{2}$ has also noted the successes of the new political parties in various contexts (e.g. Charvát 2014; Maškarinec, Bláha 2014; Cirhan, Kopecký 2017; Hájek 2017; Hloušek, Kopeček 2017; Buštíková, Guasti 2018; Kopeček et al. 2018; Krčál, Naxera 2018 or Šárovec 2019). ${ }^{3}$

Against the backdrop of changes in the Czech party system and the rise of new political formations after the so-called "election earthquake" in 2010 (Hanley 2012), anti-party and antiestablishment-oriented formations (Public Affairs (VV), ANO 2011, Dawn of Direct Democracy (Úsvit) and Freedom and Direct Democracy (SPD)) have emerged in addition to standard splitter formations (TOP 09). The trend of party system transformation continued after the elections to the Chamber of Deputies 2017 when the Czech Pirate Party entered the Chamber of Deputies as a new member within the first-order election dimension, but not as a new party within the party system dimension.

This text aspires to analyse the development of the Czech Pirate Party (Piráti) in the context of the transformation of the distribution of forces within the Czech party system. One of the main goals is to bring an empirical view of one of the most successful pirate parties ever. This task is all the more urgent because, compared to other successful pirate parties, there is still no comprehensive analysis of the breakthrough success of this phenomenon in the Czech Republic that would adequately contribute to the enrichment of the current state of knowledge.

\section{Data and methods}

This single-case and qualitative study focuses on the Czech Pirate Party (Piráti, hereinafter also referred to as PP-CZ) and analyses the transformation of the position of this party in the context of its almost ten-year existence. The phenomenon of pirate parties in Europe is reflected in the professional literature (see e.g. Erlingsson, Persson 2011; Uszkai, Vică 2012; Hartleb 2013; Demker 2014; Maškarinec 2014; Miegel, Olsson 2008; Novotný 2014 and 2015; Bolleyer et al. 2015; Otjes 2019 or Svåsand 2019), especially in the context of Sweden and Germany.

At the same time, however, this does not mean that the case of the Czech Pirates would be overlooked for a long time. Czech authors (Brunclík 2010; Charvát 2015 or Maškarinec 2017), and partly also the comparative approaches of foreign authors (Jääsaari, Hildén 2015 or Zulianello 2018), devoted their attention to the Czech Pirates. However, against the backdrop of the significant success of this subject, there is a natural need to focus on this phenomenon from another possible point of view and to take into account the latest findings. There is a crucial research question to answer: How did the Czech Pirate Party's position change from the time of its establishment to the last elections to the Chamber of Deputies 2017 within the Czech party system?

\footnotetext{
${ }^{2}$ Mainly on a very successful anti-establishment protest movement ANO 2011 (comp. Cabada, Tomšič 2016; Perottino 2016; Just, Charvát 2017 or Naxera 2018).

${ }^{3}$ For a long-term insight into similarly based research outputs, see Šárovec (2018: 78-79).
} 
The text first focuses on the historical development of the Czech Pirate Party since its foundation to the present and then analyses the significant year of 2017. The analysis combines work with several important data sources. First of all, these are primary data such as the election results from the website Volby.cz provided by the Czech Statistical Office (CZSO). Furthermore, there is individual information about the political party under examination, which is publicly accessible through the Register of Political Parties and Movements of the Ministry of the Interior of the Czech Republic. Relevant outputs from media monitoring are also important sources.

This text works with data from the Chapel Hill Expert FLASH Survey from 2017. ${ }^{4}$ CHES builds on the tradition of expert questioning. Concerning the intentions of the text, attention is directed to the questions from the Populism, Corruption, and Internal Party Democracy Questions group. This group contains individual questions that experts have answered. Two groups are relevant for the analysis: a) antielite salience explores the salience of anti-establishment and anti-elite rhetoric: 0 says the topic is not important at all, 10 refers to extreme importance; b) corrupt salience analyses the salience of reducing political corruption: 0 stands for not important at all, 10 indicates extreme importance (Codebook CHES 2017: 13). The resulting value is the aggregated average of the answers of individual questioned experts; then in brackets there is the value of the standard deviation. These groups of questions were chosen due to a direct follow-up to expert CHES $2014^{5}$ interviewing to demonstrate a continuity and discontinuity within individual indicators. ${ }^{6}$ In the previous investigations, experts were not questioned about PP-CZ and, therefore, these investigations are not considered to be appropriate for the analysis.

An important methodological element is the participatory observation method. To analyse the internal processes and functioning of the party, the last three congresses of the Pirate party were visited. The first one took place on $18^{\text {th }}$ March 2017 at Impact Hub in Prague and marked preparations for the autumn 2017 elections in the Chamber of Deputies. The second one took place on $6^{\text {th }}$ and $7^{\text {th }}$ January 2018 at Orea Hotel Voroněž in Brno. This was quite a specific event for the party because the Pirates had already been party to the Chamber of Deputies. And the third one was held on $19^{\text {th }}$ and $20^{\text {th }}$ January 2019 at Hotel Palcát in Tábor where a strategy for the 2019 European Parliament elections was discussed. It was, therefore, possible to compare three congresses of the same party adequately, but in all cases they were in a diametrically different situation.

\footnotetext{
${ }^{4}$ The 2017 Chapel Hill Expert FLASH Survey was carried out in January and February 2018 and asked about party positions in 2017. This reduced survey focuses on a smaller set of EU member states and asks all the standard questions on EU placement, economic and social party positioning. In the 2017 Chapel Hill Expert Survey, 228 experts estimated the positioning of 132 parties in 14 EU member states. In the Czech Republic it was 9 parties (Czech Social Democratic Party /ČSSD/; Civic Democratic Party /ODS/; Communist Party of Bohemia and Moravia /KSČM/; Christian Democratic Union-Czechoslovak People's Party /KDU-ČSL/; TOP 09; ANO 2011, Action of Dissatisfied Citizens /ANO/; Pirate Party /Piráti/; Freedom and Direct Democracy /SPD/; Mayors and Independents /STAN/) with 14 expert evaluations (CHES 2017).

${ }^{5}$ The 2014 Chapel Hill Expert Survey provides the data on the positioning of 268 political parties on political ideology, European integration, and policy positions in 31 EU countries, including Norway, Switzerland and Turkey. The survey was administered between December 2014 and February 2015 to 337 experts specializing in political parties and European integration in one of the countries considered (CHES 2014).

${ }^{6}$ The Green Party (Strana zelených, SZ), Dawn of Direct Democracy (Úsvit přímé demokracie, Úsvit) and Party of Free Citizens (Strana svobodných občanů, SSO) were included in CHES 2014. These parties were not reflected in the CHES 2017 questionnaire. On the contrary, the Czech Pirate Party (Česká pirátská strana, Piráti), Freedom and Direct Democracy (Svoboda a prrimá demokracie, SPD) and Mayors and Independents (Starostové a nezávislí, STAN) were added in CHES 2017. In CHES 2014, 15 experts were asked about the Czech political parties' positions.
} 


\section{The Czech Pirate Party from Its Roots to the Present Beginnings}

On $19^{\text {th }}$ April 2009, a programmer Jiří Kadeřávek announced a public appeal with a petition for the creation of the Czech Pirate Party. The primary motivation was the Swedish case around The Pirate Bay; he literally wrote on the ABC Linuxu forum: "The Pirate Bay judgment was the last straw. Where someone has recently been asserting the right to decide what we can know about how we handle our personal data, spying begins to permeate the entire Internet. Because we cannot rely on traditional political elites, we must try to form a new political force" (Abclinuxu.cz 2009). ${ }^{7}$

The petition was filed on $27^{\text {th }}$ May 2009 (Lupa.cz 2009). PP-CZ ${ }^{8}$ was registered with the Czech Ministry of the Interior on $17^{\text {th }}$ June 2009, three years after the creation of the Swedish Pirates. Jiři Kadeřávek became the first vice-president, but the party subsequently underwent further personal changes (see Charvát 2015: 36). There have been a total of three chairmen at the head of the Pirates (see Table 1), and the longest serving one is the current chairman Ivan Bartoš.

Table 1: Chairmen of the Czech Pirate Party

\begin{tabular}{|c|c|}
\hline Name & In office \\
\hline Kamil Horký & $28^{\text {th }}$ June $2009-24^{\text {th }}$ October 2009 \\
\hline Ivan Bartoš & $24^{\text {th }}$ October $2009-25^{\text {th }}$ June 2013 \\
\hline Ivan Bartoš & $7^{\text {th }}$ September $2013-6^{\text {th }}$ June 2014 \\
\hline Lukáš Černohorský & $2^{\text {nd }}$ August $2014-2^{\text {nd }}$ April 2016 \\
\hline Ivan Bartoš & $2^{\text {nd }}$ April 2016 - present \\
\hline
\end{tabular}

\section{Organisation}

Regarding organisation, the statutory body of the party is the Republic Board, for which the chairman or another delegated member of the Board acts. Presently the party is headed by the chairman and four vice-chairmen. ${ }^{9}$ The party has individual regional and local associations as organisational units. From regional associations, the Regional Forum and the Regional Presidency (Wiki.pirati.cz 2018a; MVČR 2019) are lower bodies of the party. All members, ${ }^{10}$ currently numbering $972^{11}$ (Forum.pirati.cz 2019), may participate in the National Forum, which is the highest authority of the party and meets at least once a year ${ }^{12}$ (Forum.pirati.cz 2019). ${ }^{13}$ In addition to the National Forum, there is still a Republic Committee that specifies the regulations adopted by the National Forum, prepares the background for the National Forum and decides on some

\footnotetext{
${ }^{7}$ The importance of the Pirate Bay case was also confirmed by the current chairman of the party, Ivan Bartoš (Brunclík 2010: 23).

${ }^{8}$ From $19^{\text {th }}$ June 2009 to $4^{\text {th }}$ August 2011, the party registered ČPS as the acronym of its Czech name (Česká pirátská strana). Since $4^{\text {th }}$ August 2011, the official abbreviation Pirates has been used (MVČR 2019).

${ }^{9}$ The chairman of the party is Ivan Bartoš, the $1^{\text {st }}$ vice-chairwoman Olga Richterová, the $2^{\text {nd }}$ vice-chairman Radek Holomčík, the $3^{\text {rd }}$ vice-chairman Jakub Michálek and the $4^{\text {th }}$ vice-chairman Mikuláš Peksa (Pirati.cz 2018).

${ }^{10}$ The phenomenon of membership in general, cf. with the conclusions of Tomáš Cirhan and Jakub Stauber (2018).

${ }^{11}$ As of $2^{\text {nd }}$ September 2019.

${ }^{12}$ For a comparison of the last three National Forums from 2017-2019, see the final part of the text.

${ }^{13}$ The National Forum in exclusive competence is elected and removed by the Republic Board; elected members of the Republic Committee, members of Commissions and heads of Divisions establish and abolish Commissions and Divisions, approve amendments to the statutes, discuss and approve the party's annual report, annual financial report, extraordinary review of the final decision authority of the party (Wiki.pirati.cz 2018b).
} 
other, especially expert, issues. The Committee meets at least four times a year. ${ }^{14}$ Furthermore, Commissions and Divisions are also established. ${ }^{15}$

\section{Programme}

The statutes explicitly say that:

The goal of the Czech Pirate Party is to promote the fundamental human right of the human person to the free dissemination of the information received and strict protection of the citizen's privacy as a reflection of the changed reality of the information society of the $21^{\text {st }}$ century. To achieve this goal, it is necessary to revise the copying monopoly so that it cannot become an excuse for attacks on Internet freedom (Wiki.pirati.cz 2018a).

PP-CZ has long been identified as a party primarily demanding privacy, data protection, copyright change, and freedom to use the Internet (see Brunclík 2010 and Charvát 2015). ${ }^{16}$ The long-term Pirates program, which is divided into a total of six main categories (economy, democracy, public services, the open state, sharing, and civil rights) goes hand in hand with these priorities. There are three pillars above these priorities. ${ }^{17}$ One of them is the Focal Point (Ohnisko), which refers to the very roots of the Pirate movement. ${ }^{18}$

The Pirates emphasise the civic principle, from which the entire Pirate movement, including the Czech one, emerges. They are sharply opposed to technology monopolies, government secrecy, and anti-copying. They are, therefore, committed to sharing information, respecting human privacy and other human rights, as well as developing a modern and open society. In their view, sharing information leads to better decisions. The party itself emphasises that it sets an example by using a transparent bank account and transparent accounting, sharing under free licenses, using free software, open and interconnected regulations, and direct democracy in practice; it has already undertaken the first steps in this direction (Pirati.cz 2019a). ${ }^{19}$ At the same time, PP-CZ rejects the ranking on the left-right political scale (Pirati.cz 2019b).

The so-called Democratic Minimum (Demokratické minimum) is an interesting organizational element related to program definition. This is a statement that every candidate of PP-CZ must sign before any election. The other parties can join PP-CZ as well. This minimum affects the open democracy as the Pirates understand it. It obliges the candidate to vote in accordance with the program, to actively seek relevant information for a particular decision, and when approving

\footnotetext{
${ }^{14}$ In particular, the National Committee decides on membership fees, approves budget rules and rules of management, imposes tasks on the Republic Board, discusses and approves the Pirate Program, sets rules for candidates (Wiki.pirati.cz 2018c).

${ }^{15}$ Commissions are a collegiate body of the party comprised of at least three party members and several party supporters. The highest possible number of members of the commission is seven, with the aim of fulfilling a specific task by a resolution of the National Forum. Divisions are the monocratic authorities of a party composed of a leader and possibly several party members and party supporters, and their task is to fulfil specific tasks by a resolution of the National Forum (Wiki.pirati.cz 2018a).

${ }^{16}$ Thematic anchorages and relevance of the topic cf. with the conclusions of the analyses from J. K. White and D. M. Shea (2004); M. Brunclík and M. Novák et al. (2014); G. Lachapelle and P. J. Maarek (2015); S. Ghernaouti (2016) or D. Karpf (2016).

${ }^{17}$ It is Focal Point (Ohnisko), Democratic Minimum (Demokratické minimum) and the Pirates' Twelve (Pirátské Dvanáctero).

${ }^{18}$ It even directly refers to the Pirate Bay case when it says: "On 31 ${ }^{\text {st }}$ May 2006, 65 police officers entered the Pirate Bay server room. They seized all the servers, including those that had nothing to do with the portal. In April 2009, The Pirate Bay operators were sentenced to one year in prison and a fine of 80 million crowns. They were condemned for helping people share" (Pirati.cz 2019a).

${ }^{19}$ PP-CZ makes a strong appeal for a change: "Now it is time to restart the system and advance to the next level" (Pirati.cz 2019a).
} 
binding rules, they only require the support for a proposal that the candidate is familiar with and has appropriately and relevantly commented on (Pirati.cz 2019c).

\section{International Cooperation}

The basic principles of Pirate politics are reflected in the Pirates' Twelve (Pirátské Dvanáctero), titled "A Program That We Can Share". The Pirates are reporting to the worldwide Pirate movement (Pirati.cz 2019b). Furthermore, it is indeed true that PP-CZ is significantly involved in international Pirate organisations.

First of all, it is Pirate Parties International (PPI), an international organisation covering the Pirate movement. ${ }^{20}$ In April 2012, even the Czech Pirate Party in Prague hosted a Pirate International conference, which was attended by more than 200 representatives from 27 pirate parties of the world. The primary objective of this initiative is to improve the coordination of joint actions on the European field, but also to enhance mutual communication and informal relations (iROZHLAS.cz 2012).

Another such significant organization is the European Pirate Party (PPEU), sometimes also called The European Pirates (PIRATES). ${ }^{21} \mathrm{PP}-\mathrm{CZ}$ was one of the founding members and is represented in the presidency of this organization. The goal of this organisation is to represent the European Pirate movement towards the European institutions and to work in the interest of its members. This group is aiming to be a link between European Pirate parties and Pirate MEPs (European-pirateparty.eu 2019). The President of the PPEU is Markéta Gregorová for the period of 2018-2019, one of the two vice-presidents is Mikuláš Peksa (Wiki.ppeu.net 2018a).

And last but not least, it is necessary to mention Young Pirates of Europe (YPE) as the umbrella organisation of youth Pirate parties' organizations. ${ }^{22}$ Its chairman was a Czech MP František Kopřiva. ${ }^{23}$ Czech Young Pirates (Mladí Piráti) have also been part of YPE since 2018 (Twitter.com 2018; Forum.pirati.cz 2018a). It is a club founded in 2013 by Vojtěch Pikal. However, it is not a very active part of the Czech Pirate Party system, as some young supporters enter directly into PP-CZ at the age of 18. For this reason, the Pirate Party does not focus too much on this organisation (Echo24.cz 2018).

\section{The 2017 election year as a turning point for PP-CZ?}

In 2010, the Czech Pirate Party took part in the first possible first-order elections since its inception. Although there were breakthroughs that altered the character of the party system in the sense that two new political subjects (TOP 09 and VV, see Bureš 2012 or Šárovec 2019) were successful, the Pirates achieved less than one per cent (see Table 2).

In the 2010 local elections, they got three seats. They were not successful in the regional elections in 2012 (CZSO 2010a and 2012a). The party achieved its first major success in the

\footnotetext{
${ }^{20}$ Pirate Parties International was formed in 2010 at a conference in Brussels (PPI.net 2018).

${ }^{21}$ Members of PPEU include Pirate parties from Austria, Belgium, Croatia, Estonia, Finland, France, Germany, Greece, Iceland, Italy, Luxembourg, Netherlands, Norway, Poland, Romania, Spain (Pirates de Catalunya and Confederación Pirata), Sweden, Switzerland and Slovenia. Observer members are Young Pirates of Europe, The Pirate Group in the European Parliament, Pirate Party Japan, Stadtverband Potsdam (as part of Piratenpartei Brandenburg, and Piratepartei Deutschland), Pirate Parties International and the Pirate Party of Bavaria (Wiki.ppeu.net 2018b).

${ }^{22}$ YPE has eight member organisations: \#hyperlinks from Austria, Falanster from Belarus, Mladi Piráti from the Czech Republic, Piraattinuoret from Finland, Europe Beyond Division from Germany, Ungir Piratar from Iceland, Mladi Pirati Slovenije from Slovenia and Ung Pirat from Sweden (Young-pirates.eu 2019).

${ }^{23}$ At the age of 21, he was one of the youngest MPs, alongside Dominik Feri (from TOP 09) and Tereza Hythová (from SPD) (Psp.cz 2017).
} 
2012 Senate elections. The Pirate Party nominated its candidates in the electoral districts No. 41 Benešov and No. 59 Brno-city, but they were not successful in either case. ${ }^{24}$ The joint candidate with Christian-Democrats (KDU-ČSL) and Green Party (Strana zelených, SZ) was a financial analyst Libor Michálek in the electoral district No. 26 Prague 2. He won the second round of the election with $74.39 \%$ of votes. Thanks to this, PP-CZ became the first Pirate party in history to get a seat for one of its nominees in Parliament. This has been pointed out by some media as well as by Rick Falkvinge (Ceskapozice.lidovky.cz 2012; Falkvinge 2012). However, it should be emphasized that it was a joint candidate of three parties.

In the early elections to the Chamber of Deputies of the Parliament of the Czech Republic in 2013, PP-CZ managed to win more votes, but the result of slightly more than $2.5 \%$ did not secure them any seat (Table 2). A year later, in the 2014 European Parliament elections, PP-CZ almost succeeded in joining colleagues from Sweden and Germany when they received $4.78 \%$ of votes (CZSO 2014a). ${ }^{25}$ In the autumn 2014 local elections, PP-CZ managed to get 21 seats altogether, ${ }^{26}$ with four seats in Prague. The victory and the post of the mayor then reached the spa town of Mariánské Lázně in West Bohemia (CZSO 2014b) ${ }^{27}$ In the regional elections of 2016, PP-CZ received a total of 5 seats (CZSO 2016).

Regarding possible success, however, the party focused on the Chamber of Deputies in 2017. It managed to succeed with $10.79 \%$ of the votes and 22 out of 200 seats, achieving the best result ever since its inception (see Table 2). ${ }^{28}$ This is how PP-CZ ranked alongside their colleagues from Iceland in the success of the national parliamentary elections.

Table 2: PP-CZ in the Chamber of Deputies elections 2010-2017

\begin{tabular}{lccc}
\hline & $\begin{array}{c}\text { Votes } \\
\text { (total) }\end{array}$ & $\begin{array}{c}\text { Votes } \\
\text { (in \%) }\end{array}$ & $\begin{array}{c}\text { Seats } \\
\text { (out of 200) }\end{array}$ \\
\hline $\mathbf{2 0 1 0}$ & $\mathbf{4 2 3 2 3}$ & $\mathbf{0 . 8 0}$ & $\mathbf{0}$ \\
difference 2006 vs. 2010 & +42323 & +0.80 & 0 \\
$\mathbf{2 0 1 3}$ & $\mathbf{1 3 2} \mathbf{4 1 7}$ & $\mathbf{2 . 6 6}$ & $\mathbf{0}$ \\
difference 2010 vs. 2013 & +90094 & +1.86 & 0 \\
$\mathbf{2 0 1 7}$ & $\mathbf{5 4 6 3 9 3}$ & $\mathbf{1 0 . 7 9}$ & $\mathbf{2 2}$ \\
difference 2013 vs. 2017 & +413976 & +8.13 & +22 \\
\hline & Source: CZSO $(2010 \mathrm{~b}, 2013$ and 2017a)
\end{tabular}

As shown in Table 3 below, PP-CZ ranked the third. The clear winner of the election was ANO. However, three parties were able to achieve a gain of about 10 per cent of the votes, which confirms the relatively small spans between all the profits of the total votes.

\footnotetext{
${ }^{24}$ Lenka Matoušková in Benešov or Patrik Doležal in Brno-city did not make it to the second round (CZSO 2012b).

${ }^{25}$ In this regard, the Pirates and the Green Party (with $3.77 \%$ ) filed a complaint to the Supreme Administrative Court (Nejvyšší správní soud, NSS) to abolish the $5 \%$ closing clause (Novinky.cz 2014). The petition for annulment of the clause was submitted to the Constitutional Court (Ústavní soud, ÚS). However, the Constitutional Court stated that the closing clause in the European Parliament election law is compatible with the principles of a democratic rule-of-law (Usoud.cz 2015). PP-CZ was not satisfied with this decision. The Social Democratic Prime Minister, Bohuslav Sobotka (ČSSD), whose party ended up the second in the European elections to the winning ANO, was also in favour of maintaining the five percent closure clause (iROZHLAS.cz 2015).

${ }^{26} 21$ seats on separate candidate lists. In addition to this, other seats in various electoral coalitions.

${ }^{27} \mathrm{PP}-\mathrm{CZ}$ was successful in other cities, which, in a comparative view of other European countries, was noted by Piratetimes.net (2014).

${ }^{28}$ The entry of PP-CZ to the Chamber of Deputies brought about another historical milestone. It had never happened before, that siblings who were in one of the political parties were given seats. However, it was just two Pirate candidates - Olga Richterová and Mikuláš Ferjenčík are siblings (Lidovky.cz 2017a).
} 
Table 3: Elections to the Chamber of Deputies 2017 results

\begin{tabular}{|c|c|c|c|}
\hline & $\begin{array}{l}\text { Votes } \\
(\text { in } \%)\end{array}$ & $\begin{array}{l}\text { Votes } \\
\text { (total) }\end{array}$ & $\begin{array}{l}\text { Seats } \\
\text { (out of } 200 \text { ) }\end{array}$ \\
\hline $\begin{array}{l}\text { ANO - ANO } 2011 \\
\text { (populist, entrepreneurial, anti-establishment) }\end{array}$ & 29.64 & 1500113 & 78 \\
\hline $\begin{array}{l}\text { ODS - Civic Democratic Party } \\
\text { (conservative-liberal) }\end{array}$ & 11.32 & 572962 & 25 \\
\hline $\begin{array}{l}\text { Piráti - Czech Pirate Party } \\
\text { (direct democracy, copyright, transparency) }\end{array}$ & 10.79 & 546393 & 22 \\
\hline $\begin{array}{l}\text { SPD - Freedom and Direct Democracy } \\
\text { (right-wing populist, direct democracy, entrepreneurial) }\end{array}$ & 10.64 & 538574 & 22 \\
\hline $\begin{array}{l}\text { KSČM - Communist Party of Bohemia and Moravia } \\
\text { (communist) }\end{array}$ & 7.76 & 393100 & 15 \\
\hline $\begin{array}{l}\text { ČSSD - Czech Social Democratic Party } \\
\text { (social democrats) }\end{array}$ & 7.27 & 368347 & 15 \\
\hline $\begin{array}{l}\text { KDU-ČSL - Christian and Democratic Union } \\
\text { (Christian-democratic) }\end{array}$ & 5.80 & 293643 & 10 \\
\hline $\begin{array}{l}\text { TOP } 09-\text { TOP } 09 \\
\text { (conservative-liberal) }\end{array}$ & 5.31 & 268811 & 7 \\
\hline $\begin{array}{l}\text { STAN - Mayors and Independents } \\
\text { (local politics, liberal conservatism) }\end{array}$ & 5.18 & 262157 & 6 \\
\hline
\end{tabular}

Source: CZSO (2017a)

From the shifts of voters between political parties, ${ }^{29}$ it was just the Pirates and ANO who were able to get the most voters from other political parties. The Pirates gained over 400000 new votes, almost the same as ANO. Similarly, as with ODS, they gained a very significant number of voters from TOP 09; other voters were recruited from the ranks of non-voters and voters of non-parliamentary parties, in particular the Green Party. To a lesser extent, PP-CZ was able to gain the former ODS or ANO voters (Hlidacipes.org 2017).

Picture 1 below shows the areas of voting support for the Pirates in the 2017 Elections to the Chamber of Deputies of the Parliament of the Czech Republic. The stronger line shows the division of the $\mathrm{CR}$ into individual regions, the weaker line then the administrative districts of municipalities with extended powers (SO ORP). Each colour shade represents one fifth of the total number of valid votes which PP-CZ received in the Czech Republic. This is the share of the total number of votes for the party within the Czech Republic, taking into account the share of votes for the Czech Pirate Party within the administrative districts of municipalities with extended powers (SO ORP) (see CZSO 2017b). The map shows a significant disproportion between the results in Bohemia and the results in Moravia or Silesia. In Bohemia, the Pirates achieved the lowest support in the northwest, more specifically in the Ústí nad Labem Region. The party won a high proportion of votes in Bohemia (with exceptions). The Pirates gained the strongest support in Prague and Mariánské Lázně. The party failed to win a strong support in Moravia and Silesia in the east, except for the big cities.

\footnotetext{
${ }^{29}$ It is an estimation based on the method of ecological inference, comparing the results from 2013 and 2017 at the level of more than 14000 electoral districts of the Czech Republic (Hlidacipes.org 2017).
} 


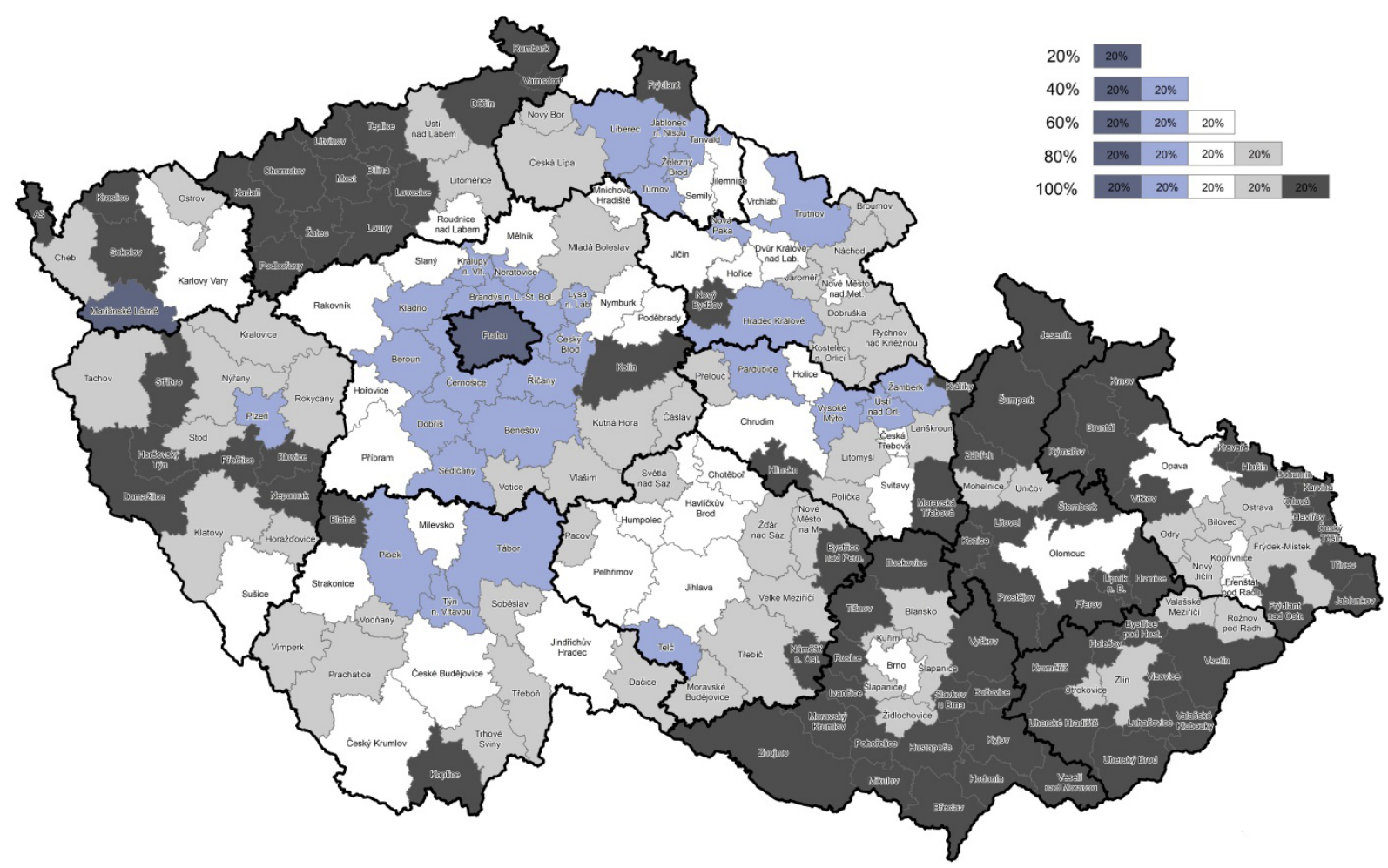

Source: CZSO (2017b)

\section{Important issues for PP-CZ}

The year 2017 was significant for PP-CZ. In March 2017, one of STEM's election models attributed $5.5 \%$ of the votes to the Pirates, which would mean crossing the $5 \%$ threshold and entering the Chamber of Deputies. The party chairman Ivan Bartoš himself said in response to the election that he expects a result of about ten per cent (iDNES.cz 2017). Before the elections, the Pirates presented the program titled "New Ideas for the New Age". The main points promoted as "steps to achieve a free, rich, digitally interconnected society" included the checks on power and the powerful ones, the facilitation of the state by technology, the protection of citizens from bullying and the defence of freedom. They marked their election program as "Black on White" in conjunction with the two main colours used not only in the party logo but also in most of the visuals (Pirati.cz 2017a).

The main slogans of the campaign, often depicted on black-and-white visuals, were such slogans like "Not everybody steals!", 30 "Let us go after them!". ${ }^{31}$ On the web page of the "Pirates electoral guidepost" under the program, there are the following introductory words of the PP-CZ chairman:

We are the only party unrelated to scandals, corruption, and bureaucracy. We've been here for eight years. We defend freedom, bring fresh ideas and are not afraid to say what we think. Politicians promise the moon, bright tomorrows and other empty

\footnotetext{
${ }^{30}$ As an allusion to the motto "Everyone steals!" ascribed to the chairman of ANO and current Prime Minister of the Czech Republic, Andrej Babiš. However, he has always dismissed this statement (Demagog.cz 2017).

${ }^{31}$ According to Behavio, this slogan was the best of all. Voters were able to identify it very well with PP-CZ (Behavio.cz 2017). This slogan also appeared in the "Let us go after them - we will fight for you!" choice, especially in the hot phase of the campaign. (e.g. Pirati.cz 2017c).
} 
catchwords. The Pirates offer clear and concrete goals - black on white. Let us go after them! (Ivan Bartoš, a party leader; Pirati.cz 2017b)

As stated by the election strategist of PP-CZ, ${ }^{32}$ the main topic according to a pre-election analysis was not digitisation, but protest issues. ${ }^{33}$ Issues such as the direct revocability of politicians, the transparency of public contracts, and the material responsibility of officials (Markething.cz 2017) proved to be crucial. This can be put into a wider context with the overall position of PP-CZ within the Czech party system in terms of protest topics.

As shown in Tables 4 and 5, the Chapel Hill Expert Survey can capture the questions about both anti-establishment and anti-elite rhetoric as well as the importance of reducing political corruption. In summary, these questions are from the Populism, corruption, and Internal Party Democracy Questions group. ${ }^{34}$

Table 4: Protest appeals of the Czech political parties according to CHES 2014

\begin{tabular}{|c|c|c|c|c|c|c|c|c|c|c|c|}
\hline & ČSSD & ODS & KSC̆M & $\begin{array}{c}\text { KDU- } \\
\text { ČSL }\end{array}$ & Greens & TOP 09 & ANO & Dawn & $\begin{array}{c}\text { Free } \\
\text { citizens }\end{array}$ & Pirates & STAN \\
\hline $\begin{array}{l}\text { Anti-establishment and } \\
\text { anti-elite rhetoric }\end{array}$ & $\begin{array}{c}1.50 \\
(1.51)\end{array}$ & $\begin{array}{c}2.15 \\
(2.30)\end{array}$ & $\begin{array}{c}5.69 \\
(2.75)\end{array}$ & $\begin{array}{c}2.46 \\
(2.26)\end{array}$ & $\begin{array}{l}5.85 \\
(1.52)\end{array}$ & $\begin{array}{c}1.92 \\
(2.06)\end{array}$ & $\begin{array}{c}7.77 \\
(2.39)\end{array}$ & $\begin{array}{c}9.46 \\
(0.97)\end{array}$ & $\begin{array}{c}7.00 \\
(2.24)\end{array}$ & $\mathrm{n} / \mathrm{a}$ & $\mathrm{n} / \mathrm{a}$ \\
\hline $\begin{array}{l}\text { Reducing political } \\
\text { corruption }\end{array}$ & $\begin{array}{c}5.23 \\
(1.74)\end{array}$ & $\begin{array}{c}3.15 \\
(2.38)\end{array}$ & $\begin{array}{c}5.46 \\
(1.56)\end{array}$ & $\begin{array}{c}5.54 \\
(2.44)\end{array}$ & $\begin{array}{l}7.00 \\
(2.13)\end{array}$ & $\begin{array}{c}5.08 \\
(2.50)\end{array}$ & $\begin{array}{c}8.54 \\
(1.45)\end{array}$ & $\begin{array}{c}8.62 \\
(1.39)\end{array}$ & $\begin{array}{c}6.00 \\
(1.56)\end{array}$ & $\mathrm{n} / \mathrm{a}$ & $\mathrm{n} / \mathrm{a}$ \\
\hline
\end{tabular}

Source: CHES (2014), own calculation

Table 5: Protest appeals of the Czech political parties according to CHES 2017

\begin{tabular}{|c|c|c|c|c|c|c|c|c|c|c|c|}
\hline & ČSSD & ODS & KSČM & $\begin{array}{c}\text { KDU- } \\
\text { ČSL }\end{array}$ & Greens & TOP 09 & ANO & Dawn & $\begin{array}{c}\text { Free } \\
\text { citizens }\end{array}$ & Pirates & STAN \\
\hline $\begin{array}{l}\text { Anti-establishment and } \\
\text { anti-elite rhetoric }\end{array}$ & $\begin{array}{c}1.93 \\
(1.38)\end{array}$ & $\begin{array}{c}2.36 \\
(1.98)\end{array}$ & $\begin{array}{c}6.79 \\
(2.75)\end{array}$ & $\begin{array}{c}1.64 \\
(1.28)\end{array}$ & $\mathrm{n} / \mathrm{a}$ & $\begin{array}{c}1.64 \\
(1.15)\end{array}$ & $\begin{array}{c}9.14 \\
(1.03)\end{array}$ & $\begin{array}{c}9.93 \\
(0.27)\end{array}$ & $\mathrm{n} / \mathrm{a}$ & $\begin{array}{c}8.15 \\
(1.28)\end{array}$ & $\begin{array}{c}2.31 \\
(1.70)\end{array}$ \\
\hline $\begin{array}{l}\text { Reducing political } \\
\text { corruption }\end{array}$ & $\begin{array}{c}4.71 \\
(1.94)\end{array}$ & $\begin{array}{c}5.29 \\
(2.64)\end{array}$ & $\begin{array}{c}5.79 \\
(2.69)\end{array}$ & $\begin{array}{c}4.43 \\
(1.79)\end{array}$ & $\mathrm{n} / \mathrm{a}$ & $\begin{array}{c}5.64 \\
(2.24)\end{array}$ & $\begin{array}{c}8.64 \\
(2.65)\end{array}$ & $\begin{array}{c}8.50 \\
(2.82)\end{array}$ & $\mathrm{n} / \mathrm{a}$ & $\begin{array}{c}9.00 \\
(1.36)\end{array}$ & $\begin{array}{c}6.23 \\
(2.05)\end{array}$ \\
\hline
\end{tabular}

Source: CHES (2017), own calculation

Unfortunately, Table 4 does not offer data for PP-CZ, because at the time of collection it was a party outside the Chamber of Deputies and its role was not very significant. ${ }^{35}$ However, the comparison of the established and new parties is interesting in terms of the importance of interparty competition. Two new entities, ANO and Dawn, showed high aggregated averages in both queries, similarly to Free Citizens and Green Party.

Table 5, on the contrary, does not offer data for the Green Party and Free Citizens. On the other hand, comparable data are available for both PP-CZ and STAN. By shifting the dimensions of individual appeals, it is evident that PP-CZ ranked next to $\mathrm{ANO}$ and $\mathrm{SPD}^{36}$ in the importance of anti-establishment and anti-elite rhetoric. In the case of the importance of reducing political corruption, PP-CZ, with its appeal, is the most striking of all political parties. The conclusions of Table 5 go hand in hand with the results of internal surveys available to the PP-CZ marketing team (Markething.cz 2017). ${ }^{37}$

\footnotetext{
${ }^{32}$ The election strategist was Jakub Horák, a marketing expert, writer, and film producer. In addition to Jakub Horák, the Czech advertising expert Josef Havelka and people from Perfect Crowd also took part in the campaign (see Markething.cz 2017).

${ }^{33}$ Horák himself said that from his point of view, the Pirates are simply a protest (Markething.cz 2017).

${ }^{34}$ See Data and Methodology part above.

${ }^{35}$ See part above.

${ }^{36} \mathrm{SPD}$ is a true follower of Dawn, so the text compares these parties as well (see Šárovec 2019).
} 
One of the key elements in the campaign was volunteers who distributed the so-called Pirate Sheets (Pirátské Listy), of which they handed out almost a million copies. ${ }^{38}$ The social networking campaign was also significant (Markething.cz 2017). ${ }^{39}$ According to Jakub Horák, there was in principle no inspiration from abroad, even though he openly discussed this matter at the PP-CZ National Forum. ${ }^{40}$ However, he met with members of the Icelandic Pirate Party ${ }^{41}$ (Lidovky.cz 2017b).

PP-CZ used a special prison bus in the campaign, ${ }^{42}$ which was used in the past by the Prison Service of the Czech Republic (Markething.cz 2017). It symbolizes the unresolved legal cases of former or current politicians over the last few years. ${ }^{43}$ At the same time, the main pillars of the Pirate program dominated the bus (Pirati.cz 2017b). In this way, the appeal of the protest was intensified, and this instrument went hand in hand with strong protest slogans focusing on other political subjects. ${ }^{44}$

Furthermore, a pre-election video was another specific campaign feature; it showed the chairman Ivan Bartoš driving this bus, but also playing the accordion and singing. Along with him, other party candidates were included in the clip (YouTube.com 2017). PP-CZ also bet on another means of transport, which was a pirate solar-powered ship (Pirati.cz 2017d). ${ }^{45}$ An important offline communication channel was the Pirate Sheets. Volunteers and supporters had the opportunity to use the party's promotional items, whether it was to attach badges to clothing, to fit a private vehicle, or to place a canvas on a house or garden. The party declared that the campaign was based mainly on volunteer donors (Pirati.cz 2017e).

\section{The direction of PP-CZ after the election "super-success" in 2017}

Generally speaking, PP-CZ has brought the importance of new themes to the Czech inter-party competition. This is confirmed by the fact that people listed the following keywords as the main reasons for voting for the party: "like, Bartoš, youth, presentation, program, change, digitisation, transparency, new party, acceptability" (Behavio.cz 2017).

\footnotetext{
${ }^{37}$ As noted in the methodological part of the text, each resulting value is the aggregated average of the answers of individual questioned experts; in brackets under there is the value of the standard deviation. This is the same for both Tables 4 and 5 .

${ }^{38}$ However, the voluntary initiative is an essential aspect of the functioning of PP-CZ as a whole.

${ }^{39}$ Marketing communication respected the fact that it was a bottom-up created party (Markething.cz 2017).

${ }^{40}$ See the final part of the text comparing PP-CZ congresses.

${ }^{41}$ On $4^{\text {th }}$ September 2017, PP-CZ organized a conference called "Pirates of the digital age: A view from Iceland". The main speakers were Icelandic Pirates Smári McCarthy, a member of Althing (Icelandic Parliament), and Helgi Hrafn Gunnarsson, a former deputy MP. The conference was presented by Ivan Bartoš, PP-CZ chairman (Tyinternety.cz 2017). It was another interesting step towards direct pre-election co-operation with successful Icelandic colleagues. ${ }^{42}$ On the bus there was the slogan "Pirate electoral tour prisoner bus", as well as one of the main campaign slogans "Let us go after them!" with the addition of "Because we are the watchdogs".

${ }^{43}$ Jana Nečasová, formerly Nagyová, generated high media interest in the PP-CZ campaign. Nečasová was depicted on the side of the bus as a woman holding a puppet resembling former Prime Minister Petr Nečas, referring to a case of alleged misuse of military intelligence. She did not like it, and so she sued PP-CZ; the lawsuit was finally withdrawn by Nečasová, but thanks to this dispute, the prison bus of PP-CZ was subjected to more media interest (Denik.cz 2018a).

${ }^{44}$ In the Czech electoral campaigning history, this is a very common means used especially in election campaigns before the elections to the Chamber of Deputies. Before the Pirates, the current president of the Czech Republic, Miloš Zeman, used the bus probably most effectively when he first travelled around the Czech Republic on his "Zemák bus" in 1996 as chairman of ČSSD. Later, buses were also used by other political groups, such as the later party of Miloš Zeman, called the Party of Civic Rights - Zeman's people (SPOZ), but also the Civic Democratic Party (ODS) or Sovereignty-block of Jana Bobošíková (Suverenita). (Radiozurnal.rozhlas.cz 2016; Busportal.cz 2006 or iDNES.cz 2010).

${ }^{45}$ For this part of the PP-CZ campaign, they organised a crowdfunding project on Hithit.com. The goal was to raise CZK 350 000, but they ended up raising CZK 743 579, more than a double (Hithit.com 2017).
} 
From the standpoint of the internal functioning and the first entry of this political party into the Chamber of Deputies, the Code of a Pirate MP (Kodex pirátského poslance) is noteworthy. It was directed to all potential PP-CZ candidates in the elections to the Chamber of Deputies in 2017. By a written consent, the candidate undertook, in the event of his election, to follow its principles and was thus included in the candidate list. The preamble to the Code reads: "Pirates want to function as a well-knit team in the Chamber of Deputies. We want our MPs to strengthen the party's good name and to be readable partners to themselves and to others" (Pirati.cz 2017f). The entire Code had five main points, namely a commitment to the Pirate party, personal honesty, transparency of personal circumstances, a conflict of interest and the fight against corruption. Violation of the given principles is legally enforceable according to the Code, except for the exercise of the mandate, where the Constitution of the Czech Republic does not allow it (Pirati.cz 2017f). It is a relatively specific approach in the Czech Republic, which PP-CZ MPs are voluntarily bound to.

The Code was ultimately followed by the so-called Pirates' Post-Electoral Strategy for the 2017 Elections to the Chamber of Deputies (Povolebni strategie Pirátu pro volby do Poslanecké sněmovny 2017). It was a document in which PP-CZ identified itself as a liberal, democratic, centrist party with a consistent anti-corruption program. The primary goal was to promote the program, whether in a coalition or in opposition. Moreover, the Strategy determined not only 20 program priorities of PP-CZ but also offered various alternatives to the relationship with the government. It means that the Strategy dictated how to act in the case the party won, participated in the government or became part of the opposition. The post-election strategy further specified the necessary conditions for the party in these individual situations (Pirati.cz 2017g). ${ }^{46}$ This move was made by PP-CZ as the only party in the elections. Members of PP-CZ approved the document in an internet vote on $15^{\text {th }}$ August 2017 (Pirati.cz 2017h). The Strategy, though declared a part of the electoral program, did not become an utterly undisputable document. The possibility was accepted of reworking it through a parliamentary club, which would have to be approved by the Republic Committee (Pirati.cz 2017g).

PP-CZ, as a newcomer in the Chamber of Deputies, remained a coherent party, which, thanks to the previously approved procedures and approaches listed above, had a clearly defined direction of its operation. After the 2017 elections, the party became an opposition party, thus fulfilling one of the possible and previously discussed scenarios of its post-election strategy.

In this context, it should be noted that on $16^{\text {th }}$ August 2018, an entity named the Moravian and Silesian Pirate Party (Moravská a Slezská pirátská strana) with the abbreviation of MS Pirates was registered with the Ministry of the Interior of the Czech Republic. One of the registered fans of PP-CZ Karel Světnička was behind the project. ${ }^{47}$ The new party ${ }^{48}$ was, in his words, a reaction to the current policy and focus of PP-CZ. MS Pirates put two candidates in the Senate - one of them was Karel Světnička, the other was a former political prisoner Michal Drabík. ${ }^{49}$ PP-CZ has

\footnotetext{
${ }^{46}$ Also, the Strategy was committed to defining what to do during the elections and immediately after the elections. Other points were the internal affairs of the parliamentary club, including its relation to the party, or the senators. The Strategy also voiced support for a nationwide referendum (Pirati.cz 2017g).

${ }^{47} \mathrm{He}$ sought a nomination for the fall Senate elections in 2018 for the Moravian-Silesian Region, but received 0 votes out of 20 possible.

${ }^{48}$ In this context, from the point of view of theoretical concepts of new political parties, this case would be classified as a split-off party (Š́rovec 2019).

${ }^{49}$ In the Senate elections, none of these candidates reached the seat.
} 
distanced itself from the new subject and refused this activity (Denik.cz 2018b). ${ }^{50}$ However, in the end this tension was very marginal and it did not harm PP-CZ (see Šárovec 2019).

A very significant success for the party, which of course enjoyed much higher interest of journalists, was the election result in the local elections in the fall of 2018. In these elections, it managed to get a total of 270 seats. ${ }^{51}$ It was a rapid increase compared to the 2010 and 2014 local elections. PP-CZ managed to retain the post of the Mayor of Mariánské Lázně. What was more significant, however, was the fact that it reached the position of the Mayor of Prague. Also, PP-CZ has two mayors of Prague's city districts and the mayor of Loket (iROZHLAS.cz 2018; Lemonde.fr 2018 and Piratskelisty.cz 2019).

PP-CZ has 376 municipal representatives, 13 representatives in the City Council of Prague and a total of 4 senators $^{52}$ after the 2018 elections (Pirati.cz 2018; Volebnimodely.pirati.cz 2018). Another challenge not only for PP-CZ but also for other European Pirate parties, was the 2019 European Parliament elections. ${ }^{53}$

There is one more thing that documents the dynamics of the transformation of the internal functioning of this political party. It includes regular national party forums held each year. Based on observation, the three last events of this type can be compared. As shown in Table 6 below, each of them had significant topics.

Table 6: Last three party congresses (National Forums) 2017-2019

\begin{tabular}{|c|c|c|}
\hline Place & Date & Main agenda \& important points \\
\hline $\begin{array}{l}\text { Prague } \\
\text { Impact } H u b\end{array}$ & $18^{\text {th }}$ March 2017 & $\begin{array}{l}\text { - preparations for } 2017 \text { elections } \\
\text { - appearance of foreign guests } \\
\text { - introduction of regional electoral leaders } \\
\text { - debate over the format of the electoral campaign }\end{array}$ \\
\hline $\begin{array}{l}\text { Brno } \\
\text { Orea Hotel Voroněžz }\end{array}$ & $6^{\text {th }}$ and $7^{\text {th }}$ January 2018 & $\begin{array}{l}\text { - voting for a new party leadership } \\
\text { - preparation for } 2018 \text { elections } \\
\text { - chairman of PP-CZ Ivan Bartoš again } \\
\text { - reflection on electoral success and work in Ch. of D. }\end{array}$ \\
\hline $\begin{array}{l}\text { Tábor } \\
\text { Hotel Palcát }\end{array}$ & $19^{\text {th }}$ and $20^{\text {th }}$ January 2019 & $\begin{array}{l}\text { - preparations for } 2019 \text { elections } \\
\text { - election of a leader for the EP election } \\
\text { - debate over the format of the electoral campaign } \\
\text { - appreciation of the party's transformation process }\end{array}$ \\
\hline
\end{tabular}

Source: Own participating observations (Forum PP-CZ 2017, 2018 and 2019)

The National Forum was held in 2017 in an atmosphere where favourable opinion polls internally strengthened PP-CZ, but it was still a party outside the Chamber of Deputies. The forum held a wide-ranging internal debate, discussing the strategy for the PS 2017 election, but also honouring foreign guests - Rick Falkvinge and Julia Reda (Forum PP-CZ 2017). ${ }^{54}$ The 2018 National Forum

\footnotetext{
${ }^{50}$ The subject's registered office was located at the Prague address Zvoníčkova 1927/5, which is the address of the Hvězda dormitory (translated as Star), one of the dormitories of Charles University. Since $29^{\text {th }}$ April the main office has been in Havírov (MVČR 2019). The whole issue sparked a debate on PP-CZ internet forum (Forum.pirati.cz 2018 b).

${ }^{51} 270$ seats on separate candidate lists. In addition to this, other seats in various electoral coalitions.

${ }^{52}$ These senators were nominated with the support of PP-CZ, so they are not independent PP-CZ candidates.

${ }^{53}$ In the 2019 European Parliament elections, according to the chairman of PP-CZ they expect up to $20 \%$ of votes (Ceskenoviny.cz 2019), although they do not consider themselves to be only a party for city liberals (Info.cz 2019).

${ }^{54}$ It was even possible to get Rick Falkving's book called Swarmwise in a Czech translation.
} 
in Brno, where a new party leadership was elected, was more significant. This election, which was conducted electronically through the Helios system, was defended by Ivan Bartoš. On the second day, working groups were held (Forum PP-CZ 2018). The 2019 National Forum was tasked with electing the leader of the European Parliament PP-CZ electoral list. A software specialist Marcel Kolaja became the leader through electronic voting done via the Helios system. Other spots on the ballot were discussed, as well as the post-election strategy, campaign strategy, and changing of the statutes. ${ }^{55}$ Thematic workshops were held the next day (Forum PP-CZ 2019).

In this respect, three diametrically different positions of $\mathrm{PP}-\mathrm{CZ}$ can be observed in this direction: in March 2017, the party was a potential newcomer and was about to reach its highest potential or the highest chance of breaking through the first-order elections. In January 2018, it was a successful party that was comparable to that of Iceland. The whole forum was an object of much more significant media interest. Finally, in January 2019, the party was ready to confidently surpass its very promising outcome of the 2014 European Parliament elections.

However, if the analysis remains in the dimension of national politics, it is evident that the dynamic growth of the party's success has been a part of the party system for several years, but more in the marginal sense. In this respect, the election campaign in the fall of 2017 reflected this reality. PP-CZ has proved to be one of the most successful pirate parties in the world.

\section{Conclusion}

The Czech Pirate Party celebrates its tenth anniversary in 2019. Regarding the analysis of PPCZ's activities in this first decade, it can be said that it is a party that has achieved several significant successes in the global Pirate movement. And it does not matter whether this refers to the success of 2012, when the first ever Pirate nominee came into Parliament, or to the year 2014, when PP-CZ just closely missed getting into the European Parliament and thus did not become the third Pirate party - alongside the Swedish and German Pirate parties - to achieve this. However, the year 2017 was significant, when PP-CZ first got into the Chamber of Deputies and was thus comparable to its colleagues from Iceland.

From a long-term analysis, it would be a mistake to say that the year 2017 was an unexpected breakthrough. The upward trend was evident in a survey of voting preferences in March 2017, which for the first time showed PP-CZ to have more than five percent of votes. This potential party was confirmed in the fall of 2017, and it was for the first time in its history when it entered the Chamber of Deputies. This success is comparable to the results of the heretofore most successful Icelandic Pirates. ${ }^{56} \mathrm{PP}-\mathrm{CZ}$ began following its election strategy approved before the elections and became part of the opposition.

The year 2017 can, therefore, be perceived by PP-CZ as a certain culmination of a gradual ascension or gradual minor successes respectively. PP-CZ became a new party in the Chamber of Deputies, but not a new party within the party system. The success of PP-CZ must be understood given the overall changes within the party system - whether voter shifts, voters' disappointment in the established or new parties. PP-CZ is for many voters an alternative to a liberal subject who communicates (not only) digital themes for the $21^{\text {st }}$ century. However, in 2017, PP-CZ's success was significant thanks to promoting "protest" issues. It is a challenge for further research to analyse not only the new development of the party system as such but also the internal mechanisms of PP-CZ's functioning. It is a bottom-up party that can work very well and efficiently

\footnotetext{
${ }^{55}$ The transformation of the party was also a specific feature. Ivan Bartoš spoke about the Upgrade project, which was launched in 2018 to improve the party's internal functioning. This comprehensive project took place in March and covered some themes, for example the operation of the leadership of PP-CZ, proposals for regulation, and stabilisation of what works (Piratskelisty.cz 2019).

${ }^{56}$ In the dimension of national elections or first-order elections (FOE).
} 
with volunteers and sympathisers. At the same time, it is a party that was able to maintain electoral support in the following local elections of 2018 and, moreover, gained the post of the Mayor of Prague. However, any comprehensive evaluation of overall success and other ambitions of PP-CZ are at a very early stage.

This text represents one of the systematic contributions to the analysis of the Czech Pirate Party as one of the most successful pirate parties to date, not only in Europe but also in the world. In regards to external electoral and political challenges, as well as to internal organisational and developmental changes, the most appropriate way is to stay and continue to deepen the onedimensional, comparative or generally thematically broadly oriented direction of research.

\section{Funding}

The work was supported by the grant SVV number 260461 Interests, power, and institutions in political decision-making.

\section{Note}

The first version of this text was presented in August 2018 at the ECPR General Conference in Hamburg, Germany; the second version was released in December 2018 at the workshop Cyber Parties: New Parties, ICTs and Organization in the Digital Age organized by the Department of Constitutional Law and Political Science, School of Law, University of Valencia, Spain.

\section{Bibliography}

Abclinuxu.cz. 2009. "Petice pod vznik České pirátské strany." [online] Abclinuxu.cz, 19. 4. 2009 [cit. 2. 9. 2019]. Available from: http://www.abclinuxu.cz/blog/BoodOk/2009/4/petice-pod-vznik-ceskapiratske-strany.

Ait-Aoudia, M. 2018. "Conditions for new parties' participation in a founding election in a democratic transition: The Algerian case." Party Politics 24 (4), 434-443, https://doi.org/10.1177/1354068816667387.

Bakke, E., N. Sitter. 2015. "Where do parties go when they die? The fate of failed parties in the Czech Republic, Slovakia, and Hungary 1992-2013." East European Politics 31 (1), 1-22, https://doi.org/ 10.1080/21599165.2014.959661.

Behavio.cz. 2017. "VOLBY 2017: Volební rozhodování, kampaně a povolební realita." [online] Behavio.cz [cit. 2. 9. 2019]. Available from: https://mapavolicu.behavio.cz/downloads/BEHAVIO_volby_2017 kampane_a_povolebni.pdf.

Bolleyer, N., C. Little, F-Ch. von Nostiz. 2015. "Implementing Democratic Equality in Political Parties: Organisational Consequences in the Swedish and the German Pirate Parties." Scandinavian Political Studies 38 (2), 158-178, https://doi.org/10.1111/1467-9477.12044.

Bolleyer, N., E. Bytzek. 2017. "New party performance after breakthrough: Party origin, building and leadership." Party Politics 23 (6): 772-782, https://doi.org/10.1177/1354068815626604.

Brunclík, M. 2010. "Pirátské strany: nový fenomén v politice." Naše společnost 8 (1), 21-29.

Brunclík, M., M. Novák et al. 2014. Internetové volby: budoucnost, nebo slepá ulička demokracie? Praha: Sociologické nakladatelství.

Burě̌, J. 2012. "Volby v České republice v roce 2010: fenomén nových stran TOP 09 a VV." Politics in Central Europe 8 (2), 141-151.

Busportal.cz. 2006. "Autobusy ve volbách: Zemák a ty druhé." [online] Busportal.cz, 12. 4. 2006 [cit. 2.9. 2019]. Available from: http://www.busportal.cz/modules.php?name=article\&sid=1726.

Buštíková, L., P. Guasti. 2018. "The State as a Firm: Understanding the Autocratic Roots of Technocratic Populism." East European Politics and Societies: and Cultures, OnlineFirst, 1-29. https://doi.org/ $10.1177 / 0888325418791723$.

Cabada, L., M. Tomšič. 2016. "The Rise of Person-Based Politics in the New Democracies: The Czech Republic and Slovenia." Politics in Central Europe 12 (2), 29-50, https://doi.org/10.1515/pce-20160011. 
Ceskapozice.lidovky.cz, 2012. "Světový závod o prvního piráta v národním parlamentu vyhráli nečekaně Češi." [online] Ceskapozice.lidovky.cz, 22. 10. 2012 [cit. 2. 9. 2019]. Available from: http:// ceskapozice.lidovky.cz/svetovy-zavod-o-prvniho-pirata-v-narodnim-parlamentu-vyhrali-necekane-cesi1br-/tema.aspx?c=A121022_151604_pozice_80775.

Ceskenoviny.cz, 2019. "Piráty povede do eurovoleb Marcel Kolaja, chtějí 20 procent." [online] Ceskenoviny.cz, 19. 1. 2019 [cit. 2. 9. 2019]. Available from: https://www.ceskenoviny.cz/zpravy/piraty-povededo-eurovoleb-marcel-kolaja-chteji-20-procent/1710324.

Charvát, J. 2014. "The Czech Party System Change since 2010: From Fragile Stability to Stable Fragility." Revista de Stiinte Politice/Revue des Sciences Politiques 41, 141-154.

Charvát, J. 2015. "Pravice nebo levice? Analýza ideologie pirátských stran." Central European Journal of Politics 1 (1), 29-39.

Charvát, J., P. Just. 2016. Krize politického stranictví a noví straničtí aktéri v české politice. Praha: Metropolitan University Prague Press.

CHES 2014 and 2017. "Explaining the salience of anti-elitism and reducing political corruption for political parties in Europe with the 2014 Chapel Hill Expert Survey data." Research \& Politics (January-March): $1-9$.

Cirhan, T., J. Stauber. 2018. "Online supporter and registered sympathiser as alternatives to a regular party member." East European Politics 34 (4), 458-482, https://doi.org/10.1080/21599165.2018.1532410.

Cirhan, T., P. Kopecký. 2017. "Career Backgrounds, Professional Network and Party Cohesion: The Success of ANO in the Czech Republic." Politologický časopis/Czech Journal of Political Science 24 (2): 116-136, https://doi.org/10.5817/PC2017-2-116.

Codebook CHES. 2017. "Chapel Hill Expert Survey 2017. Codebook." [online] [cit. 2. 9. 2019]. Available from: https://static1.squarespace.com/static/5975c9bfdb29d6a05c65209b/t/5abd3f57758d460daa65c 360/1522351961283/CHES+2017+Codebook.pdf.

CZSO. 2010a. "Volby do zastupitelstev obcí." [online] Volby.cz [cit. 2. 9. 2019]. Available from: https:// volby.cz $/$ pls $/ \mathrm{kv} 2010 / \mathrm{kv} 1211$ ? $\mathrm{xjazyk}=\mathrm{CZ} \& \mathrm{xid}=0 \& \mathrm{xv}=1 \& \mathrm{xdz}=7 \& \mathrm{xnumnuts}=0 \& \mathrm{xstat}=1 \& \mathrm{xvyber}=1$.

CZSO. 2010b. "Volby do Poslanecké sněmovny Parlamentu České republiky konané ve dnech 28.05. 29.05.2010." [online] Volby.cz [cit. 2. 9. 2019]. Available from: https://volby.cz/pls/ps2010/ ps2? xjazyk=CZ.

CZSO. 2012a. "Volby do zastupitelstev krajů konané ve dnech 12.10. - 13.10.2012." [online] Volby.cz [cit. 2. 9. 2019]. Available from: https://www.volby.cz/pls/kz2012/kz63?xjazyk=CZ\&xdatum $=20121012$.

CZSO. 2012b. "Volby do Senátu Parlamentu ČR konané ve dnech 12.10. - 13.10.2012." [online] Volby.cz [cit. 2. 9. 2019]. Available from: https://volby.cz/pls/senat/se2?xjazyk=CZ\&xdatum=20121012.

CZSO. 2013. "Volby do Poslanecké sněmovny Parlamentu České republiky konané ve dnech 25.10. 26.10.2013." [online] Volby.cz [cit. 2. 9. 2019]. Available from: https://volby.cz/pls/ps2013/ ps2?xjazyk=CZ.

CZSO. 2014a. "Volby do Evropského parlamentu konané na území České republiky ve dnech 23.05. 24.05.2014." [online] Volby.cz [cit. 2. 9. 2019]. Available from: https://volby.cz/pls/ep2014/ ep11? xjazyk=CZ.

CZSO. 2014b. "Volby do zastupitelstev obcí." [online] Volby.cz [cit. 2. 9. 2019]. Available from: https:// volby.cz $/ \mathrm{pls} / \mathrm{kv} 2014 / \mathrm{kv} 1211$ ? xjazyk $=\mathrm{CZ} \& \mathrm{xid}=0 \& \mathrm{xv}=1 \& \mathrm{xdz}=7 \& \mathrm{xnumnuts}=0 \& \mathrm{xstat}=1 \& \mathrm{xvyber}=1$.

CZSO. 2016. "Volby do zastupitelstev krajů konané ve dnech 7.10. - 8.10.2016." [online] Volby.cz [cit. 2. 9. 2019]. Available from: https://volby.cz/pls/kz2016/kz63?xjazyk=CZ\&xdatum $=20161007$.

CZSO. 2017a. "Volby do Poslanecké sněmovny Parlamentu České republiky konané ve dnech 20.10. 21.10.2017 (promítnuto usnesení NSS)." [online] Volby.cz [cit. 2. 9. 2019]. Available from: https:// volby.cz/pls/ps2017nss/ps2?xjazyk=CZ.

CZSO. 2017b. "Oblasti územní volební podpory Piráti." [online] Volby.cz, 31. 5. 2018 [cit. 2. 9. 2019]. Available from: https://www.czso.cz/documents/10180/61449410/22002918m3.jpg/23dd606c-e2cb-4f3ba1ac-15203eb462aa?version $=1.0 \& \mathrm{t}=1526461094471$.

Demagog.cz. 2017. "Andrej je gentleman." [online] Demagog.cz, 8. 2. 2017 [cit. 2. 9. 2019]. Available from: https://demagog.cz/diskuze/andrej-je-gentleman.

Demker, M. 2014. "Sailing Along New Cleavages: Understanding the Electoral Success of the Swedish Pirate Party in the European Parliament Election 2009." Government and Opposition 49 (2): 188-206. https://doi.org/10.1017/gov.2013.24. 
Denik.cz. 2018a. "Nečasová stáhla žalobu na Piráty. Musí zaplatit náklady soudu." [online] Denik.cz, 12. 1. 2018 [cit. 2. 9. 2019]. Available from: https://www.denik.cz/z_domova/necasova-stahla-zalobu-napiraty-musi-jim-zaplatit-naklady-20180112.html.

Denik.cz. 2018b. "Politické vody brázdí další piráti. Odpadlík Světnička si založil vlastní stranu." [online] Denik.cz, 16. 8. 2018 [cit. 2. 9. 2019]. Available from: https://www.denik.cz/z_domova/politicke-vodybrazdi-dalsi-pirati-odpadlik-svetnicka-si-zalozil-vlastni-stranu-20180816.html.

Echo24.cz. 2018. "Nástupci někdejších svazáků? Svo̊j dorost mají i konzervativci a Piráti." [online] Echo24.cz, 19. 3. 2018 [cit. 2. 9. 2019]. Available from: https://echo24.cz/a/SFXaU/nastupci-nekdejsichsvazaku-svuj-dorost-maji-i-konzervativci-a-pirati.

Emanuele, V., A. Chiaramonte. 2018. "A growing impact of new parties: Myth or reality? Party system innovation in Western Europe after 1945." Party Politics 24 (5), 475-487, https://doi.org/10.1177/ 1354068816678887.

Erlingsson, G. Ó., M. Persson. 2011. "The Swedish Pirate Party and the 2009 European Parliament Election: Protest or Issue Voting?" Politics $31 \quad$ (3), 121-128. https://doi.org/10.1111/ j.1467-9256.2011.01411.x.

European-pirateparty.eu. 2019. "European Pirate Party." [online] European-pirateparty.eu [cit. 2. 9. 2019]. Available from: https://european-pirateparty.eu/statues/.

Falkvinge, R. 2012. "Pirate Parties Win First Senator's Seat, Czech Win International Race." [online] Falkvinge.net, 21. 10. 2012 [cit. 2. 9. 2019]. Available from: http://falkvinge.net/2012/10/21/pirateparties-win-first-senators-seat-czech-win-international-race/.

Filipec, O. 2019. "Challenging Trends within Slovak Party System in the Context of 2016 Elections to the National Council of the Slovak Republic." Politics in Central Europe 15 (1), 7-34, https://doi.org/ 10.2478/pce-2019-0001.

Forum PP-CZ. 2017. "Own participating observation at PP-CZ Forum." Impact Hub, Prague, $18^{\text {th }}$ March 2017.

Forum PP-CZ. 2018. "Own participating observation at PP-CZ Forum." Orea Hotel Voroněž, Brno, $6^{\text {th }}$ and $7^{\text {th }}$ January 2018.

Forum PP-CZ. 2019. "Own participating observation at PP-CZ Forum." Hotel Palcát, Tábor, $19^{\text {th }}$ January 2019.

Forum.pirati.cz. 2019. "Celostátní forum." [online] Forum.pirati.cz [cit. 2. 9. 2019]. Available from: https:// forum.pirati.cz/memberlist.php?mode=group\&g $=47$.

Forum.pirati.cz. 2018a. "YPE (Evropští mladí Piráti)." [online] Forum.pirati.cz [cit. 2. 9. 2019]. Available from: https://forum.pirati.cz/viewtopic.php?t=17608.

Forum.pirati.cz. 2018b. "Moravská a slezská pirátská strana." [online] Forum.pirati.cz [cit. 2. 9. 2019]. Available from: https:/ forum.pirati.cz/viewtopic.php?f=75\&t=43311\&start $=10$.

Ghernaouti, S. 2016. Sécurité informatique et réseaux. Malakoff: Dunod.

Hájek, L. 2017. "Left, Right, Left, Right. . C Centre: Ideological Position of Andrej Babiš's ANO." Politologický časopis/Czech Journal of Political Science 24 (3), 275-301, https://doi.org/10.5817/PC2017-3275.

Hanley, S. 2012. "Dynamics of new party formation in the Czech Republic 1996-2010: looking for the origins of a 'political earthquake'." East European Politics 28 (2), 119-143, https://doi.org/10.1080/ 21599165.2012 .669733$.

Hartleb, F. 2013. "Anti-elitist cyber parties?" Journal of Public Affairs 13 (4), 355-369. https://doi.org/ $10.1002 /$ pa.1480.

Hithit.com. 2017. "Pirátská plavba do Sněmovny." [online] Hithit.com [cit. 2. 9. 2019]. Available from: https://www.hithit.com/cs/project/3805/piratska-plavba-do-snemovny.

Hlidacipes.org. 2017. "Přehledně: Kdo komu bral a kam utekly hlasy. Nejvíc ,loupili“ ANO a Piráti." [online] Hlidacipes.org, 23. 10. 2017 [cit. 2. 9. 2019]. Available from: https://hlidacipes.org/prehledne-bral-kamutekly-hlasy-nejvic-loupili-ano-pirati/.

Hloušek, V., L. Kopeček. 2017. "Different Ways of Institutionalising Entrepreneurial Parties: Czech Public Affairs Party and ANO." Politologický časopis/Czech Journal of Political Science 24 (2), 92-115, https://doi.org/10.5817/PC2017-2-92.

Hynčica, P., D. Šárovec. 2018. "Slovenské politické strany optikou konceptu novosti." Acta Fakulty filozofické Západočeské univerzity v Plzni 10 (2-3), 7-34, https://doi.org/10.24132/actaff.2018.10.2-3.1. 
iDNES.cz. 2010. "Bobošíková ,opsala' od Zemana zemák. Česko objíždí s Bobobusem." [online] iDNES.cz, 22. 1. 2010 [cit. 2. 9. 2019]. Available from: https://www.idnes.cz/zpravy/domaci/bobosikova-opsalaod-zemana-zemak-cesko-objizdi-s-bobobusem.A100122_182450_domaci_vel.

iDNES.cz. 2017. "Do Sněmovny by prvně zasedli i piráti, říká průzkum. Bartoš v úspěch věří." [online] iDNES.cz, 17. 3. 2017 [cit. 2. 9. 2019]. Available from: https://www.idnes.cz/zpravy/domaci/volbypruzkum-stem-brezen-2017-pirati-top09.A170317_153405_domaci_ekl.

Info.cz, 2019. "Lídr Pirátů do eurovoleb: nejsme jen stranou městských liberálů." [online] Info.cz, 20. 1. 2019 [cit. 2. 9. 2019]. Available from: https://www.info.cz/volby/volby-do-evropskeho-parlamentu/lidrpiratu-do-eurovoleb-nejsme-jen-stranou-mestskych-liberalu-39718.html.

iROZHLAS.cz. 2012. ",Piráti" se v Praze dohodli na vytvoření evropské strany." [online] iROZHLAS.cz, 15. 4. 2012 [cit. 2. 9. 2019]. Available from: https://www.irozhlas.cz/zpravy-domov/-pirati-se-v-prazedohodli-na-vytvoreni-evropske-strany_201204152123_epres.

iROZHLAS.cz. 2015. "Návrh na změnu pětiprocentní klauzule pro volbu do EP u Ústavního soudu neuspěl." [online] iROZHLAS.cz, 1. 6. 2015 [cit. 2. 9. 2019]. Available from: https://www.irozhlas.cz/zpravydomov/navrh-na-zmenu-petiprocentni-klauzule-pro-volbu-do-ep-u-ustavniho-souduneuspel_201506012005_vkourimsky.

iROZHLAS.cz. 2018. "Krnáčová předala Prahu Pirátovi Zdeňkovi Hřibovi. Primátor chce ,chytré ř́ízení města." [online] iROZHLAS.cz, 15. 11. 2018 [cit. 2. 9. 2019]. Available from: https://www.irozhlas.cz/ zpravy-domov/zdenek-hrib-pirati-hlavni-mesto-praha-primator_1811151424_mal.

Jääsaari, J., J. Hildén. 2015. "From File Sharing to Free Culture: The Evolving Agenda of European Pirate Parties." International Journal of Communication 9, 870-889.

Just, P., J. Charvát. 2017. "Business-Firm Parties and the Czech Party System after 2010." Politics in Central Europe 12 (3), 83-110, https://doi.org/10.1515/pce-2016-0018.

Karpf, D. 2016. Analytic activism: digital listening and the new political strategy. New York: Oxford University Press.

Kopeček, L., V. Hloušek, R. Chytilek, P. Svačinová. 2018. Já platím, já rozhoduji!: političtí podnikatelé a jejich strany. Brno: B\&P Publishing.

Kosowska-Gąstoł, B., K. Sobolewska-Myślik. 2017. "New Political Entrepreneurs in Poland." Politologický časopis/Czech Journal of Political Science 24 (2), 137-157, https://doi.org/10.5817/PC2017-2-137.

Kosowska-Gąstol, B., K. Sobolewska-Myślik. 2019. "Does Novelty Necessarily Mean Change? New Political Parties within the Polish Party System." Politics in Central Europe 15 (1), 81-113, https://doi.org/ 10.2478/pce-2019-0004.

Krašovec, A. 2017. "A Hint at Entrepreneurial Parties? The Case of Four New Successful Parties in Slovenia." Politologický časopis/Czech Journal of Political Science 24 (2), 158-178, https://doi.org/10.5817/ PC2017-2-158.

Krčál, P., V. Naxera. 2018. "Populistická konstrukce národa ohroženého migrací: CAQDAS volebního diskurzu českých parlamentních voleb v roce 2017." Sociológia 50 (5), 491-523. https://doi.org/ 10.31577/sociologia.2018.50.5.19.

Lachapelle, G., J., P. J. Maarek (eds.). 2015. Political Parties in the Digital Age: The Impact of New Technologies in Politics. Berlin/Boston: De Gruyter Oldenbourg.

Lemonde.fr. 2018. "A Prague, le nouveau maire figure de proue du Parti pirate." [online] Lemonde.fr, 10. 12. 2018 [cit. 2. 9. 2019]. Available from: https://www.lemonde.fr/international/article/2018/12/10/aprague-le-nouveau-maire-figure-de-proue-du-parti-pirate_5395484_3210.html.

Lidovky.cz. 2017a. "Historický milník. Piráti jsou první stranou, která bude mít ve sněmovně sourozence." [online] Lidovky.cz, 23. 10. 2017 [cit. 2. 9. 2019]. Available from: https://www.lidovky.cz/domov/ sourozenci-ve-snemovne-za-piraty.A171023_153712_ln_domov_rsa.

Lidovky.cz. 2017b. "Nagyová byla náš největší dobrovolník v kampani, tvrdí marketingový ,génius' Pirátů." [online] Lidovky.cz, 24. 10. 2017 [cit. 2. 9. 2019]. Available from: https://www.lidovky.cz/domov/ nagyova-byl-nas-nejvetsi-dobrovolnik-v-kampani-rika-marketingovy-geniuspiratu.A171023_150932_ln_domov_sk.

Lupa.cz. 2009. "Př́ípravný výbor podal návrh na registraci České pirátské strany." [online] Lupa.cz, 29. 5. 2009 [cit. 2. 9. 2019]. Available from: https://www.lupa.cz/tiskove-zpravy/navrh-na-registraci-ceskepiratske-strany/.

Malčič, M., A. Krašovec. 2019. "New Parties and Democracy in Slovenia." Politics in Central Europe 15 (1), 115-137, https://doi.org/10.2478/pce-2019-0005. 
Markething.cz. 2017. "S Jakubem Horákem o kampani Pirátů i Babišově polibku smrti." [online] Markething.cz, 25. 10. 2017 [cit. 2. 9. 2019]. Available from: http://markething.cz/jakub-horak.

Marušiak, J. 2017. "Political Entrepreneurs as a Challenge for the Party System in Slovakia." Politologický časopis/Czech Journal of Political Science 24 (2), 179-200, https://doi.org/10.5817/PC2017-2-179.

Maškarinec, P. 2014. "Voličská základna Švédské Pirátské strany v letech 2006-2010." Pp 501-510 in QAUERE 2014, vol. IV: Recenzovaný sborník interdisciplinární mezinárodni vědecké konference doktorandi̊ a odborných asistentů. Hradec Králové: MAGNANIMITAS.

Maškarinec, P. 2017. "The Czech Pirate Party in the 2010 and 2013 Parliamentary Elections and the 2014 European Parliament Elections: Spatial Analysis of Voter Support." Slovak Journal of Political Science 17 (1), 5-33, https://doi.org/10.1515/sjps-2017-0001.

Maškarinec, P., P. Bláha. 2014. "For whom the Bell Tolls: Grievance Theory and the Rise of New Political Parties in the 2010 and 2013 Czech Parliamentary Elections." Sociológia 46 (6), 706-731.

Miegel, F., T. Olsson. 2008. "From pirates to politicians: The story of the Swedish file shares who became a political party." Pp 203-215 in N. Carpentier et al. Democracy, Journalism and Technology: New Developments in an Enlarged Europe. Tartu: University of Tartu Press.

MVČR. 2019. "Rejstř́k politických stran a politických hnutí." [online] Mvcr.cz [cit. 2. 9. 2019]. Available from: http://aplikace.mvcr.cz/seznam-politickych-stran/Vypis_Rejstrik.aspx?id=540.

Naxera, V. 2018. "The Never-ending Story: Czech Governments, Corruption and Populist Anti-Corruption Rhetoric (2010-2018)." Politics in Central Europe 14 (3), 31-54, https://doi.org/10.2478/pce-20180017.

Novinky.cz, 2014. "Zelení a piráti podali stížnost na výsledky eurovoleb, chtějí zrušit hranici pěti procent." [online] Novinky.cz, 6. 6. 2014 [cit. 2. 9. 2019]. Available from: https://www.novinky.cz/domaci/338589zeleni-a-pirati-podali-stiznost-na-vysledky-eurovoleb-chteji-zrusit-hranici-peti-procent.html.

Novotný, L. 2014. "Liquid democracy a Pirátská strana v Německu." Acta Politologica 6 (2), 154-165.

Novotný, L. 2015. "Piráti v berlínské poslanecké sněmovně: bilance jejich dosavadního působení." Central European Journal of Politics 1 (1), 1-16.

Otjes, S. 2019. "All on the same boat? Voting for pirate parties in comparative perspective." Politics, OnlineFirst, 1-16, https://doi.org/10.1177/0263395719833274.

Perottino, M. 2016. "The Disappearance of Politics, or Depolitization the Czech Way." Sociální studia/Social Studies 13 (1), 45-56.

Piratetimes.net. 2014. "Pirates Elected to Municipalities and Local Bodies." [online] Web.archive.org, 7. 12. 2014 [cit. 2. 9. 2019]. Available from: https://web.archive.org/web/20150603102432/http:// piratetimes.net/pirates-elected-to-municipalities-and-local-bodies-pirate-history/.

Pirati.cz. 2017a. "Program." [online] Pirati.cz [cit. 2. 9. 2019]. Available from: https://www.pirati.cz/ assets/pdf/program.pdf.

Pirati.cz. 2017b. "Nové myšlenky pro novou dobu." [online] Pirati.cz [cit. 2. 9. 2019]. Available from: https://www.pirati.cz/program/.

Pirati.cz. 2017c. "Potřebujeme vaši pomoc, nadešel čas!" [online] Pirati.cz, 22. 9. 2017 [cit. 2. 9. 2019]. Available from: https://www.pirati.cz/tiskove-zpravy/ivan-bartos-potrebujeme-vas.html.

Pirati.cz. 2017d. "Začíná pirátská plavba do Sněmovny." [online] Pirati.cz, 16. 8. 2017 [cit. 2. 9. 2019]. Available from: https://www.pirati.cz/tiskove-zpravy/piratska-lod-vyplouva.html.

Pirati.cz. 2017e. "Piráti: V kampani se opíráme především o dobrovolné dárce." [online] Pirati.cz, 26. 7. 2017 [cit. 2. 9. 2019]. Available from: https://www.pirati.cz/tiskove-zpravy/pirati-v-kampani-seopirame-predevsim-o-dobrovolne-darce.html.

Pirati.cz. 2017f. "Kodex Pirátského poslance." [online] Pirati.cz [cit. 2. 9. 2019]. Available from: https:// www.pirati.cz/program/psp2017/kodex-poslance/.

Pirati.cz. 2017g. "Povolební strategie Pirátů pro volby do Poslanecké sněmovny 2017." [online] Pirati.cz [cit. 2. 9. 2019]. Available from: https://www.pirati.cz/program/psp2017/povolebni-strategie/.

Pirati.cz. 2017h. "Piráti schválili povolební strategii." [online] Pirati.cz, 15. 8. 2017 [cit. 2. 9. 2019]. Available from: https://www.pirati.cz/tiskove-zpravy/pirati-zverejnili-povolebn\%C3\%AD-strategii.html.

Pirati.cz. 2018. "Pirátská strana." [online] Pirati.cz [cit. 2. 9. 2019]. Available from: https://www.pirati.cz/ lide/.

Pirati.cz. 2019a. "Ohnisko." [online] Pirati.cz [cit. 2. 9. 2019]. Available from: https://www.pirati.cz/ program/dlouhodoby/ohnisko/. 
Pirati.cz. 2019b. "Pirátské dvanáctero." [online] Pirati.cz [cit. 2. 9. 2019]. Available from: https:// www.pirati.cz/program/dlouhodoby/dvanactero/.

Pirati.cz. 2019c. "Demokratické minimum." [online] Pirati.cz [cit. 2. 9. 2019]. Available from: https:// www.pirati.cz/program/dlouhodoby/minimum/.

Piratskelisty.cz. 2019. "Fungující propojení domácí a evropské politiky je pro nás výzvou, uvedl Ivan Bartoš na Celostátním fóru Pirátů." [online] Piratskelisty.cz, 19. 1. 2019 [cit. 2. 9. 2019]. Available from: https://www.piratskelisty.cz/clanek-2269-fungujici-propojeni-domaci-a-evropske-politiky-jepro-nas-vyzvou-uvedl-ivan-bartos-na-celostatnim-foru-piratu.

Polášek, M., M. Perottino, V. Novotný. 2014. "Expertiza v politických stranách: téma a jeho teoretické uchopení." Politologická revue 22 (1), 147-166.

PPI.net. 2018. "About PPI." [online] Ppi.net [cit. 2. 9. 2019]. Available from: https://pp-international.net/ about-ppi/.

Psp.cz. 2017. "Poslanci." [online] Psp.cz [cit. 2. 9. 2019]. Available from: http://www.psp.cz/sqw/ hp.sqw?k=192.

Radiozurnal.rozhlas.cz. 2016. "Miloš Zeman objížděl republiku už v 90. letech. V legendárním Zemáku." [online] Radiozurnal.rozhlas.cz, 19. 4. 2016 [cit. 2. 9. 2019]. Available from: https://radiozurnal.rozhlas.cz/ milos-zeman-objizdel-republiku-uz-v-90-letech-v-legendarnim-zemaku-6233604.

Šárovec, D. 2016. "Nové politické strany: novost, teoretické koncepty a možnosti jejich využití v ČR." Politics in Central Europe 12 (2S), 9-27.

Šárovec, D. 2018. "Nástup nových politických stran v ČR od roku 2013: hnutí ANO 2011 a Úsvit přímé demokracie pohledem konceptu novosti." Sociológia 50 (1), 78-113.

Šárovec, D. 2019. "Is the 'new' always 'new'? Theoretical framework problems of new political parties' research: The Czech Republic experience." Politics in Central Europe 15 (1), 55-80, https://doi.org/ 10.2478/pce-2019-0003.

Stankov, N. 2019. "Springing up like mushrooms after the rain: 'New' parties in Montenegro's institutionalised party system." Politics in Central Europe 15 (1), 163-185, https://doi.org/10.2478/pce-2019-0007.

Svåsand, L. G. 2019. "The Swedish Pirate Party: Towards Institutionalisation?" Pp 155-169 in R. Harmel, L. G. Svøasand. Institutionalisation of Political Parties. Comparative Cases. London, Lanham: Rowman \& Littlefield International.

Twitter.com, 2018. "František Kopřiva." [online] Twitter.com, 8. 7. 2018 [cit. 2. 9. 2019]. Available from: https://twitter.com/FrantiekKopiva/status/1015920138535735297.

Tyinternety.cz. 2017. "Piráti digitálního věku: konference s islandskými poslanci." [online] Tyinternety.cz [cit. 2. 9. 2019]. Available from: https://tyinternety.cz/kalendar-akci/pirati-digitalniho-veku-konferenceislandskymi-poslanci/.

Usoud.cz. 2015. "Uzavírací klauzule v zákoně o volbách do Evropského parlamentu je slučitelná s principy demokratického právního státu." [online] Usoud.cz, 1. 6. 2015 [cit. 2. 9. 2019]. Available from: https://www.usoud.cz/aktualne/uzaviraci-klauzule-v-zakone-o-volbach-do-evropskeho-parlamentu-jeslucitelna-s-principy-demo/.

Uszkai, R., C. Vică. 2012. "How to assess the emergence of the European Pirate Parties. Towards a research agenda." Sfera Politicii 169, 46-55.

Vidal, G. 2018. "Challenging business as usual? The rise of new parties in Spain in times of crisis." West European Politics 41 (2), 261-286, https://doi.org/10.1080/01402382.2017.1376272.

Volebnimodely.pirati.cz. 2018. "Výsledky Piráti Komunál 2018." [online] Volebnimodely.pirati.cz [cit. 2. 9. 2019]. Available from: https://volebnimodely.pirati.cz/index_komunal.php.

White, J. K., D. M. Shea. 2004. New party politics: from Jefferson and Hamilton to the information age. Belmont: Wadsworth/Thomson Learning.

Wiki.pirati.cz. 2018a. "Stanovy České pirátské strany." [online] Wiki.pirati.cz [cit. 2. 9. 2019]. Available from: https://wiki.pirati.cz/rules/st.

Wiki.pirati.cz. 2018b. "Celostátní forum." [online] Wiki.pirati.cz [cit. 2. 9. 2019]. Available from: https:// wiki.pirati.cz/cf/start.

Wiki.pirati.cz. 2018c. "Republikový výbor." [online] Wiki.pirati.cz [cit. 2. 9. 2019]. Available from: https:// wiki.pirati.cz/rv/start.

Wiki.ppeu.net. 2018a. " $4^{\text {th }}$ Board of PPEU." [online] Wiki.ppeu.net [cit. 2. 9. 2019]. Available from: https://wiki.ppeu.net/doku.php?id=ppeu:board2018. 
Wiki.ppeu.net. 2018b. "Members." [online] Wiki.ppeu.net [cit. 2. 9. 2019]. Available from: https:// wiki.ppeu.net/doku.php?id=ppeu:members.

Young-pirates.eu. 2019. "Members." [online] Young-pirates.eu [cit. 2. 9. 2019]. Available from: https:// young-pirates.eu/members/.

Youtube.com. 2017. "Piráti: Pustete nás na ně. Všichni nekradou!" [online] Youtube.com [cit. 2. 9. 2019]. Available from: https://www.youtube.com/watch?v=5f0-nQLHHM4.

Zulianello, M. 2018. "Mobilizing young voters? A cross-national analysis of contextual factors in pirate voting." European Politics and Society 19 (3), 282-298. https://doi.org/10.1080/23745118.2017.1419666.

\section{About author}

Daniel Šárovec is a PhD student at the Department of Political Science, Institute of Political Studies, Faculty of Social Sciences, Charles University in Prague. His research interest focuses on political parties and especially on new political parties. His dissertation analyses the theoretical and practical aspects of new political parties' emergence and development in the Czech Republic. ORCID: https://orcid.org/0000-0003-2491-538X. 